\title{
Osteochondroma of the mandibular condyle with secondary synovial chondromatosis
}

\author{
Kyoung-A Kim*
}

Department of Oral and Maxillofacial Radiology, School of Dentistry and Institute of Oral and Bioscience, Chonbuk National University, Jeonju, Korea

\begin{abstract}
An osteochondroma is rare in the facial skeleton because of the intramembranous origin. This paper describes an uncommon case of osteochondroma of mandibular condyle with secondary synovial chondromatosis in a 43-year-old woman, who had an occlusal splint and orthodontic treatment without an accurate diagnosis for more than two years. The patient visited Chonbuk National University Hospital with the chief complaint of facial asymmetry and difficulty in chewing food by malocclusion. Cone-beam computed tomography revealed the presence of a radiopaque mass with loose bodies, which developed from the anterior portion of the right condylar neck and extended into the condylar head. The patient underwent tumor excision and condyloplasty subsequent to the clinical and radiographic diagnosis of osteochondroma with synovial chondromatosis. The histopathological diagnosis revealed osteochondroma, which consisted of proliferative bony and hyalinized cartilage tissues. The patient had been followed up for two years and there had been no evidence of recurrence.
\end{abstract}

Key Words: Osteochondroma, Chondromatosis, Mandibular condyle, Cone-beam computed tomography

(c) This is an open-access article distributed under the terms of the Creative Commons Attribution Non-Commercial License (http://creativecommons.org/licenses/by-nc/4.0) which permits unrestricted noncommercial use, distribution, and reproduction in any medium, provided the original work is properly cited.

\section{서 론}

골연골종(osteochondroma)은 골에 발생하는 가장 흔한 양성종 양으로 장골의 골간단(metaphysis)과 사지골격(appendicular skeleton)에 주로 발생한다. 구강악안면영역에서는 매우 드물지 만 발생 시 주로 하악과두와 근돌기에서 발생한다[1-9]. 하악과 두에 발생한 골연골종은 이환골의 표면으로부터 외방증식하므 로 종양이 성장함에 따라 안면 비대칭, 하악의 전돌성 편위와 이 환측의 개교합 및 반대측의 교차교합을 보이는 부정교합, 악관 절 장애, 청각 감각의 상실, 그리고 통증 등의 다양한 임상증상 을 나타낼 수 있다[3,10]. 방사선사진에서 종양은 하악과두로부 터 불규칙하게 증식된 융기형태의 방사선불투과상으로 관찰되
고, 병소의 해면골은 정상골의 해면골과 혼재되어 나타난다. 병 소와 접촉하는 인접골에서는 골경화나 골침식 등의 반응성 골 개조 양상이 동반되기도 한다. 본 증례보고에서는 반응성으로 나타난 활액연골종증(synovial chondromatosis)을 수반한 하 악과두의 골연골종 증례를 보고하고자 한다.

\section{증례보고}

43세 여성이 턱이 왼쪽으로 변위되고 위아래 이가 서로 잘 맞 지 않아 음식물 저작이 어렵다는 증상을 호소하며 전북대학교 치과병원에 내원하였다. 환자의 진술에 의하면 증상이 3년 전에 시작되어 턱이 점차적으로 좌측으로 변위되면서 현재 상태까

Received July 17, 2018; Revised August 8, 2018; Accepted August 14, 2018

Corresponding author: Kyoung-A Kim, Department of Oral and Maxillofacial Radiology, School of Dentistry, Chonbuk National University, 567 Baekje-daero, Deokjin-gu, Jeonju 54896, Korea.

Tel: +82-63-250-2220, Fax: +82-63-250-2081, E-mail: beam@jbnu.ac.kr

Copyright (๑) 2018, Oral Biology Research Institute 
지 진행되었고, 시간이 지남에 따라 음식물 저작은 더 어려워지 고 있다고 하였다. 환자는 본원을 내원하기 2년 전에 동일한 증 상으로 개인치과에 내원하여 2년 동안 치아교정치료와 구강 내 교합안정장치치료를 받았지만 치료 후에도 증상의 개선은 없었 고, 현재에도 교합안정장치를 착용하지 않으면 음식물 저작이 어렵다고 하였다. 악관절에 대한 문진에서 2년 전 우측 관절에 서 관절음과 통증이 있었다고 하였다. 환자에게 갑상선질환과 간염의 전신병력이 있었으며, 외상 등의 과거력은 없었다.

구강 외 검사에서 페구 시 하악이 좌측으로 편위되어 심한 안 면 비대칭을 보였다. 구강 내 검사에서는 좌측 구치부의 교차교 합과 하악 전치부의 반대교합 및 하악 정중선의 좌측 변위가 관 찰되었다(Fig. 1). 하악운동을 검사한 결과, 개구 시 하악이 우 측으로 편위되었고, 최대 개구량은 $36 \mathrm{~mm}$, 우측 측방 운동량 4 $\mathrm{mm}$, 좌측 측방 운동량 $3 \mathrm{~mm}$ 로 하악의 측방 운동이 제한됨을 알 수 있었다. 개·폐구 시 양측 악관절에서 관절음이나 통증은 없었다.

파노라마방사선사진에서 우측 하악과두에 중첩된 비교적 큰 방사선불투과성 종괴가 관찰되었다(Fig. 2). 두부규격방사 선사진에서는 우측 하악과두의 외하방 변위로 인해 하악의 좌 측 편위와 함께 하악 전돌이 관찰되었다(Fig. 3). Cone-beam computed tomography (CBCT)에서 외측익돌근의 부착점인 우측 하악과두의 경부로부터 돌출된 불규칙한 골성 종괴가 하 악과두를 외하방으로 변위시키면서 측두하와(infratemporal fossa) 하방에서 상방과 내측으로 성장한 양상이 관찰되었다. 종 괴의 내부는 불균일한 골소주 양상을 보였고, 변연은 하악과두 의 피질골과 이어져 피질골성 변연을 보였으나 관절와 하방에 서는 골경화와 침식으로 인해 불규칙한 외형을 보였다. 또한, 관 절와에서도 골경화가 나타났고 그 직하방에는 소성체들이 위치 해 있었다. 좌측 악관절에서도 하악과두의 불규칙한 침식과 관 절와의 골경화 양상이 관찰되었다(Fig. 4).
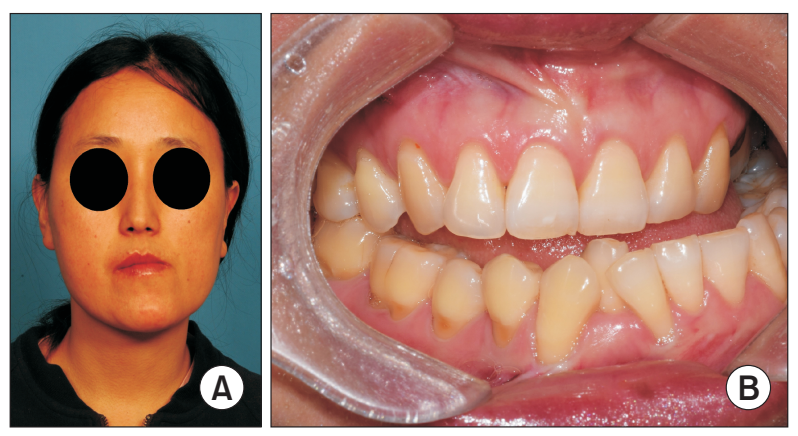

Fig. 1. Facial appearance. (A) Extraoral photograph showing facial asymmerty and chin deviation to the left side. (B) Intraoral photograph showing asymmetrical prognathism with crossbite on the left side.
임상 및 방사선학적 소견으로 우측 하악과두에 발생한 골연 골종과 반응성 이차 활액연골종증으로 진단하였다. 수술로 종 양을 제거하는 치료계획 하에 6개월의 치아교정치료를 선행하 였고, 그 후 전신마취 하에 구강 내 접근을 통해 골연골종 종괴 및 소성체들을 제거하였으며, 수술시야의 확보를 위해 우측 근 돌기도 함께 제거하였다. 수술과정에서 하악과두를 포함한 하 악지를 분리하여 외부에서 하악과두의 형태를 조정해 다시 고 정하였으며, 양측성 시상분리절골술을 시행하였다(Fig. 5). 술 후 교정치료를 지속하였고 2년의 경과 관찰 동안 재발은 일어나 지 않았다.

술 후 조직병리학적 검사에서 섬유조직, 신생골 및 연골유 리조직(cartilaginous hyaline tissue)이 있는 연골 캡(cartilaginous cap)과 미성숙 해면골을 가진 병변이 관찰되어 하악과 두의 골연골종을 확진하였다(Fig. 6).

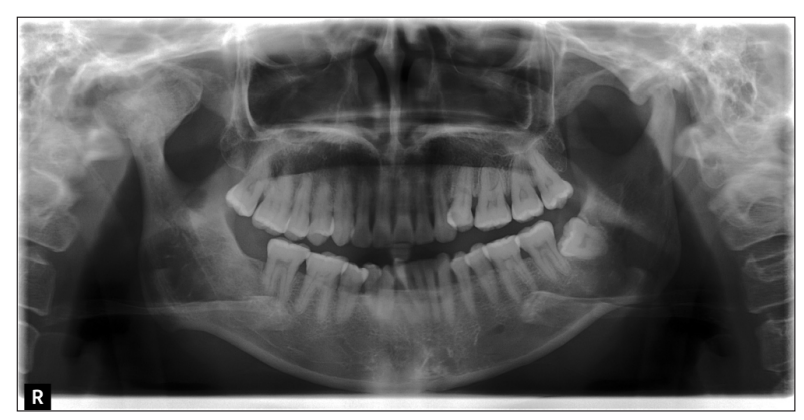

Fig. 2. Panoramic radiograph showing large radiopaque mass on the right mandibular condylar head.
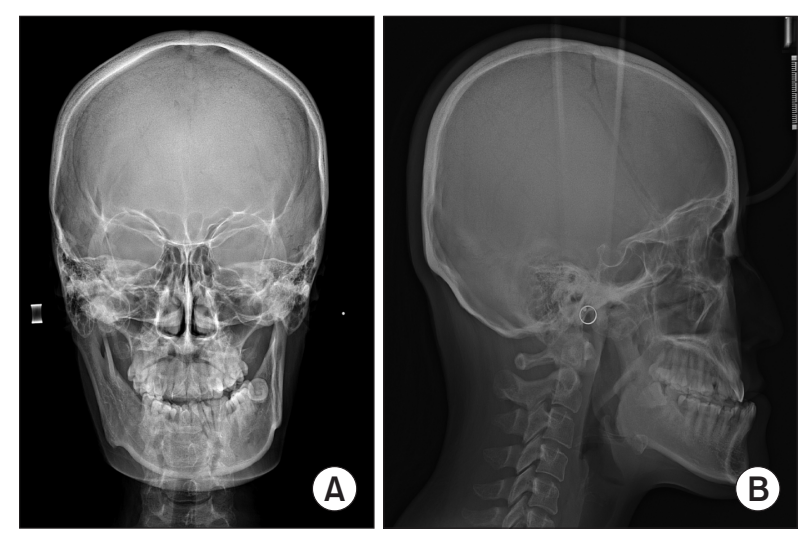

Fig. 3. Cephalometic radiographs. (A) Posteroanterior view showing deviation of mandible to the left side. (B) Lateral view showing mandibular prognathism. 

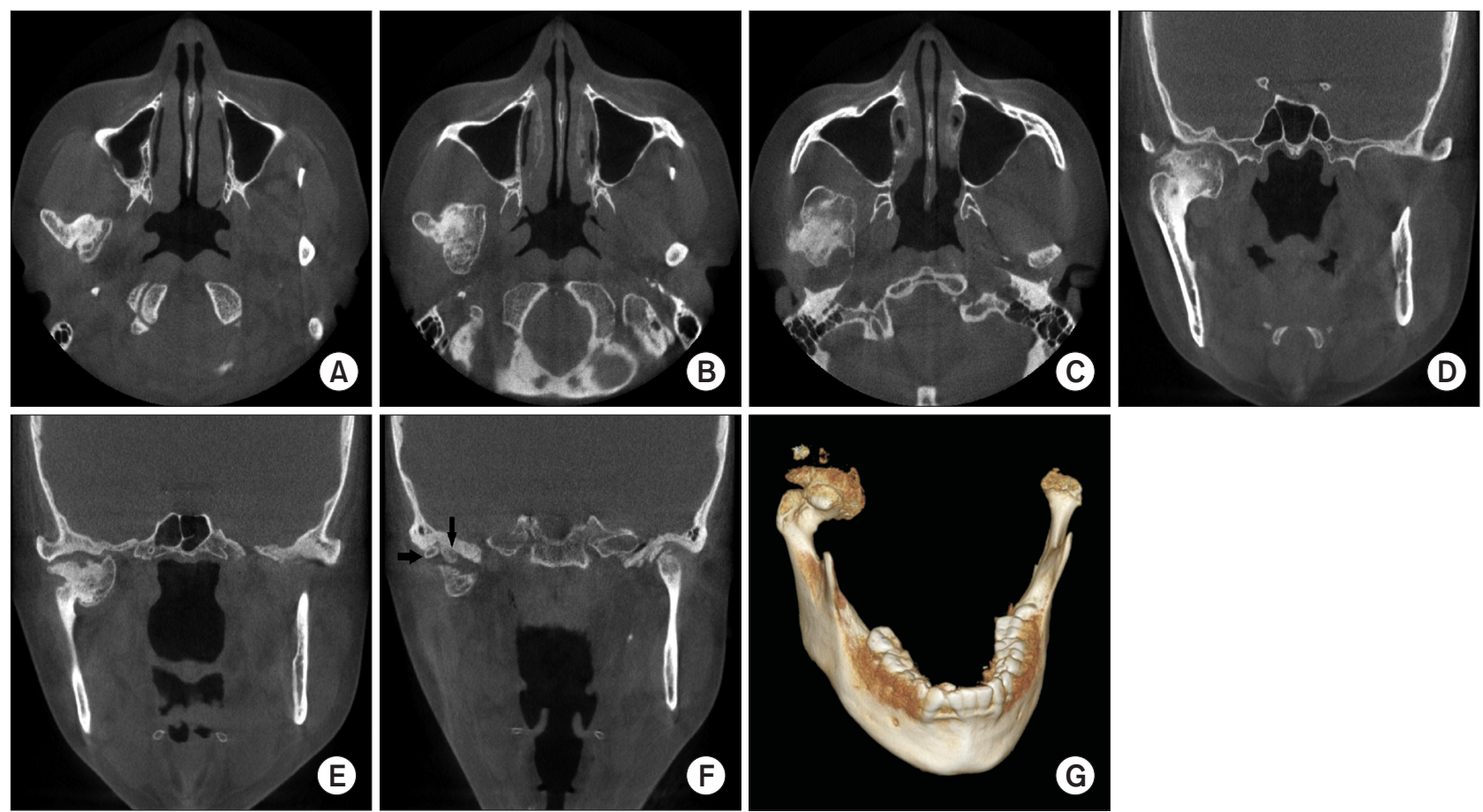

Fig. 4. Cone-beam computed tomography (CT); (A-C) Axial scans, (D-F) Coronal scans, and (G) 3D image. Cone-beam CT images show an irregular mass protruding from the neck of the right mandibular condyle. Loose bodies are observed in the right temporomandibular joint (arrows). Erosion of the condyle and sclerosis of the articular fossa were observed in the left temporomandibular joint.

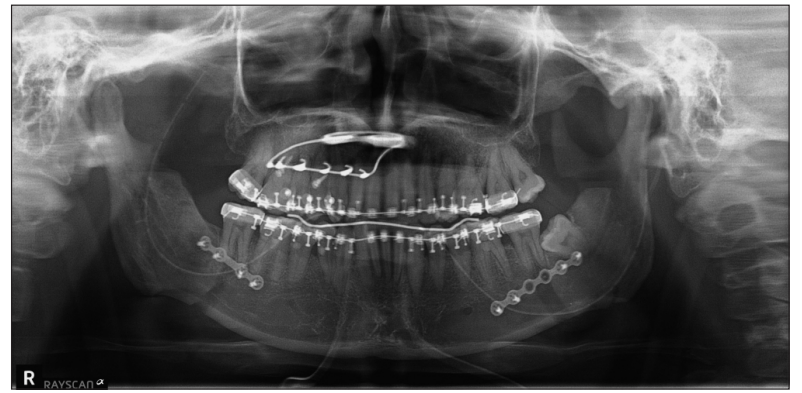

Fig. 5. Postoperative panoramic radiograph showing the mandibular condyle with the mass of osteochondroma removed.

\section{고 찰}

하악과두의 골연골종은 안면비대칭, 동통, 하악전돌, 부정교 합, 악관절의 운동제한, 그리고 청력소실 등의 임상증상을 일으 킬 수 있으며, 그 중 안면비대칭은 가장 흔히 나타나는 임상증 상이다. 일반적으로 하악과두의 골연골종은 매우 서서히 성장 하면서 하악을 점진적으로 수평 변위시키기 때문에 진단이 늦 어지는 원인이 되기도 한다[3,11,12]. 또한, 임상증상이 악관절 장애(temporomandibular disorder)와 유사하게 나타나기 때 문에 악관절장애로 오진하여 잘못된 치료를 진행하기도 한다

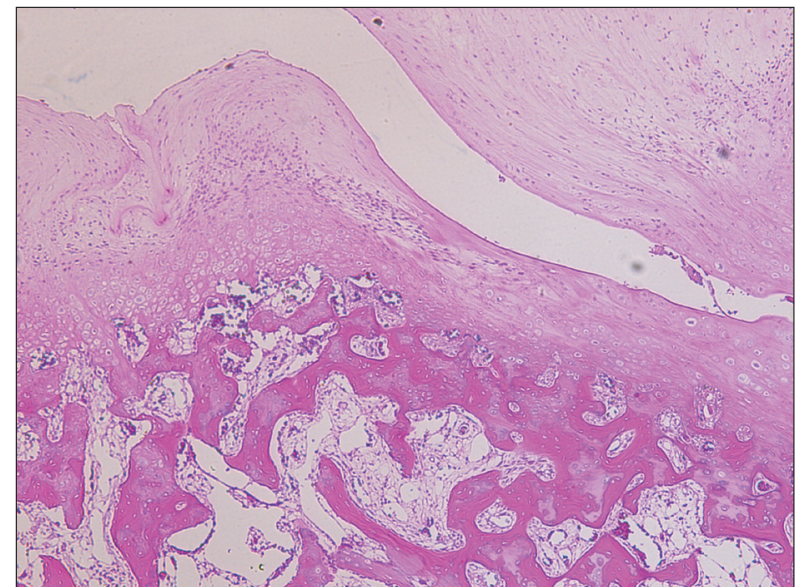

Fig. 6. Photomicrograph of the lesion of the mandibular condyle. $\mathrm{H} \& \mathrm{E}$-stained specimen shows hyaline cartilage-like tissues and bony proliferation. At border between cartilage and bone, endochondral ossification is visible ( $\mathrm{H} \& \mathrm{E}$ staining, $\times 50)$.

[13,14]. 본 증례에서도 초기에 골연골종을 발견하지 못했기 때 문에 악관절장애 및 치아교정치료를 장기간 진행하였다. 악관 절장애와 유사한 임상증상을 보이는 환자에서 진료의 오류를 범하지 않기 위해 철저한 방사선검사를 통한 정확한 진단은 필 수이다. 
하악과두의 골연골종의 발생 원인으로 다양한 견해들이 제기 되고 있지만 골막의 화생(metaplasia)으로 발생한다는 주장이 가장 유력하게 받아들여지고 있다[15]. 하악과두의 외상은 골 막의 화생를 촉발시키는 요인으로서, 보고된 많은 증례들에서 하악과두에 대한 직·간접적인 외상의 기왕력을 보고하고 있다 $[8,10,11,13]$. 그러나 본 증례에서는 특별한 외상의 기왕력은 없 었다. 축골격(axial skelton)에 발생하는 골연골종이 10대에 호 발하는 것과 달리 하악과두에 발생하는 골연골종은 본 증례처 럼 30-40대에 주로 발생한다. Saito 등[2]은 이 연령에서는 치아 상실과 구강 내 치아보철물의 증가, 악관절장애를 포함한 악관 절 질환의 증가 등이 하악과두에 미세한 외상을 일으켜 골연골 종을 야기할 수 있다고 하였다.

본 증례의 $\mathrm{CBCT}$ 영상에서는 종괴가 하악과두의 경부에서 돌 출되어 전후방, 상방, 그리고 내방으로 성장한 양상을 잘 관찰할 수 있었다. 종괴가 시작된 것으로 보이는 하악과두의 경부는 외 측익돌근의 부착부와 일치하는 지점으로서, Saito 등[2]은 하악 과두의 골연골종의 발생과 외측익돌근과의 관련성을 주장하였 다. 그는 연골로 분화될 가능성을 가진 세포가 외측익돌근과 같 은 근육의 비정상적인 스트레스에 의해 자극을 받으면 이 세포 들이 골막에서 증식하여 종양성 변화를 일으킬 수 있다고 하였 다. 그러나 Zhang 등[16]과 Meng 등[3]은 많은 하악과두의 골 연골종 증례들의 방사선학적 소견을 검토하여 골연골종이 하악 과두의 어느 부위에서나 발생함을 보여주었으며, 따라서 외측 익돌근과 골연골종의 발생은 관련이 없다고 주장하였다. 하악 과두에서 골연골종을 유도하는 골막의 화생은 외측익돌근의 비 정상적 스트레스 이외에도 다양한 원인의 미세외상에 의해 발 생함을 짐작할 수 있다.

하악과두에 발생한 골연골종은 일반적으로 하악과두에 기저 부를 갖는 자루형태로 성장하며, 이러한 양상은 방사선사진, 특 히 $\mathrm{CBCT}$ 를 통해 쉽게 확인할 수 있다[16,17]. 골연골종의 이와 같은 성장양상은 방사선학적으로 하악과두의 과증식과 감별할 수 있는 특징이 된다. 골연골종은 하악과두의 정상형태를 변형 시키면서 하악과두의 국소부위로부터 돌출된 불규칙한 종괴의 양상을 띠는 반면, 과증식은 하악과두의 정상 형태가 보존되면 서 전반적인 하악과두의 크기 증가를 보이고 하악과두 경부의 길이가 증가한 양상으로 관찰된다[2,3,11,18-21]. CBCT는 이 러한 골변화를 세밀하게 관찰할 수 있는 진단도구로서, 종괴 이 외에 종양의 성장함에 따라 나타나는 이차적인 골개조 양상을 관찰하는데도 유용하다. 종양이 성장하면서 하악과두는 관절 와에서 전하방으로 점차 변위되고 종괴와 전방 관절융기가 가 관절(psuedojoint)을 형성하게 된다. 또한, 종양이 후방으로 증 식하면서 후방 관절융기를 압박하게 되고 이 부분에서 골흡수 나 편평화 등의 골개조 양상이 나타나기도 한다[3,22,23]. 본 증
례에서도 하악과두의 불규칙한 종괴가 측두하와 하방에서 하 악과두의 전후방, 상방, 그리고 내방으로 성장함에 따라 관절와 및 관절융기와 종괴 표면에서 골개조 양상이 나타났고, 또한 이 차적인 활액연골종증을 동반하여 관절와 직하방에 소성체들이 관찰되었다. 골연골종 환자에서 이차 활액연골종증이라고 하 는 석회화된 소성체가 동반되는 원인은 명확하지 않다. 지속적 인 마찰에 의해 골연골종 외측의 소엽화된 결절이 탈락되어 소 성체가 나타난다는 주장과 성장하는 골연골종에 의한 외상이나 비정상적인 부하가 만성적으로 가해짐에 따라 활액막의 화생 (synovial metaplasia)이 일어나 활액연골종증이 발생한다는 주 장이 있다[24-29]. Helmy 등[30]은 이차 활액연골종증의 원인 으로 미세외상을 주장하였는데, 그는 원숭이를 이용한 실험을 통해 미세외상으로 인한 골관절염이 진행되는 과정에서 이차 활액연골종증이 발생함을 밝혔고, 이러한 이차 활액연골종증으 로 인해 악관절에서 관절원반의 충격흡수기능이 상실된다고 하 였다.

하악과두에 발생한 골연골종이나 활액연골종증은 악관절장 애와 유사한 증상을 보이므로 종종 악관절장애로 오진되기도 한다[13,31]. Cimino 등[13]은 몇 년 동안 지속되는 점진적인 안면비대칭이나 특별한 이유 없이 점차적으로 나타나는 개구 제한 등과 같은 악관절장애의 특징적이지 않은 징후와 증상이 나타날 때 임상의는 다른 질환을 의심해야 하고, 또한 성장이 끝 난 뒤에 교합변화가 있을 때에는 하악과두의 병소를 의심해야 한다고 보고하였다.

악관절의 골변화를 평가하기 위해서 방사선사진은 필수적이 다. 악관절 평가를 위한 대표적인 방사선촬영술로는 경두개방 사선촬영술, 파노라마방사선촬영술, CT 등이 있다. 그러나 일반 방사선사진에서는 다른 해부학적 구조의 중첩이나 촬영 시 환 자의 부적절한 위치 때문에 과두를 판독하기에 부적절한 상이 형성되어 과두의 병변이 정확하게 판독되지 못하는 경우가 있 다[13]. 그러므로 방사선촬영 시에는 과두와 주위 해부학적 구 조의 판독이 용이한 적절한 상을 얻을 수 있도록 촬영해야 한다. 본 증례의 환자는 턱이 점차적으로 좌측으로 변위되는 것을 주 소로 처음 개인치과에 내원한 것으로 보아 내원 당시의 하악의 변위는 골연골종으로 인한 것으로 볼 수 있다. 그러나 환자는 초 기에 골연골종의 방사선학적 진단이 정확히 되지 않은 상태로 장기간 악관절장애치료 및 치아교정치료 등의 부적절한 치료 를 받은 것으로 보이며, 이로 인해 골연골종에 대한 치료가 늦어 지고, 이차적으로 활액연골종증이 발생된 것으로 판단된다. 따 라서 악관절장애와 유사한 임상증상을 보이는 환자에서 진료의 오류를 범하지 않기 위해 철저한 방사선검사를 통한 정확한 진 단이 필수이며, 또한 충분한 정보를 제공할 수 있는 적절한 방사 선사진상을 얻는 것은 매우 중요하다. 


\section{CONFLICTS OF INTEREST}

The authors declare that they have no competing interests.

\section{ORCID}

Kyoung-A Kim

https://orcid.org/0000-0001-8237-8311

\section{REFERENCES}

1. Koga M, Toyofuku S, Nakamura Y, Yoshiura K, Kusukawa J, Nakamura Y. Osteochondroma in the mandibular condyle that caused facial asymmetry: a case report. Cranio 2006;24:67-70. doi: 10.1179/crn.2006.011.

2. Saito T, Utsunomiya T, Furutani M, Yamamoto H. Osteochondroma of the mandibular condyle: a case report and review of the literature. J Oral Sci 2001;43:293-297. doi: 10.2334/josnusd.43.293.

3. Meng Q, Chen S, Long X, Cheng Y, Deng M, Cai H. The clinical and radiographic characteristics of condylar osteochondroma. Oral Surg Oral Med Oral Pathol Oral Radiol 2012;114:e66-e74. doi: 10.1016/j.oooo.2012.01.016.

4. Choi WJ, Hwang EH, Lee SR. The osteochondroma of the mandibular condyle: report of a case. Korean J Oral Maxillofac Radiol 2000;30:138-143.

5. Sawada K, Schulze D, Matsumoto K, Hirai S, Hashimoto K, Honda K. Osteochondroma of the coronoid process of the mandible. J Oral Sci 2015;57:389-392. doi: 10.2334/ josnusd.57.389.

6. Losa-Muñoz PM, Burgueño-García M, González-MartínMoro J, Sánchez-Burgos R. Osteochondroma of coronoid process: a rare etiology of jacob disease. Craniomaxillofac Trauma Reconstr 2014;7:306-309. doi: 10.1055/s-00341378182.

7. Fan H, Lv X, Shi J, Hu J, Luo E. One-stage treatment to osteochondroma of the coronoid process and secondary facial asymmetry with coronoidectomy and reduction malarplasty: a case report and literature review. J Oral Maxillofac Surg 2014;72:1870.e1-1870.e13. doi: 10.1016/ j.joms.2014.04.030.

8. Jha A, Gupta P, Khalid M, Naseem I, Gupta G. Sarcomatous transformation of osteochondroma of the coronoid process forming pseudoarthrosis with zygomatic arch mistaken for Jacob disease. J Craniofac Surg 2014;25:e101-e102. doi: 10.1097/SCS.00000000000000409.

9. Coll-Anglada M, Acero-Sanz J, Vila-Masana I, NavarroCuéllar C, Ochandiano-Caycoia S, López de-Atalaya J, Navarro-Vila C. Jacob's disease secondary to coronoid process osteochondroma. A case report. Med Oral Patol Oral Cir Bucal 2011;16:e708-e710. doi: 10.4317/medoral. 16820.

10. Iizuka T, Schroth G, Laeng RH, Lädrach K. Osteochondroma of the mandibular condyle: report of a case. J Oral Maxillofac Surg 1996;54:495-501. doi: 10.1016/S02782391(96)90127-5.

11. Roychoudhury A, Bhatt K, Yadav R, Bhutia O, Roychoudhury S. Review of osteochondroma of mandibular condyle and report of a case series. J Oral Maxillofac Surg 2011;69:2815-2823. doi: 10.1016/j.joms.2010.10.016.

12. Vezeau PJ, Fridrich KL, Vincent SD. Osteochondroma of the mandibular condyle: Literature review and report of two atypical cases. J Oral Maxillofac Surg 1995;53:954963. doi: 10.1016/0278-2391(95)90293-7.

13. Cimino R, Steenks MH, Michelotti A, Farella M, PierFrancesco N. Mandibular condyle osteochondroma. Review of the literature and report of a misdiagnosed case. J Orofac Pain 2003;17:254-261.

14. Gingrass DJ, Sadeghi EM. Osteochondroma of the mandibular condyle mimicking TMJ syndrome: clinical and therapeutic appraisal of a case. J Orofac Pain 1993;7:214219.

15. Lichtenstein L. Bone tumors. 5th ed. St. Louis: Mosby; 1977.

16. Zhang J, Wang H, Li X, Li W, Wu H, Miao J, Yuan X. Osteochondromas of the mandibular condyle: variance in radiographic appearance on panoramic radiographs. Dentomaxillofac Radiol 2008;37:154-160. doi: 10.1259/ dmfr/19168643.

17. Utumi ER, Pedron IG, Perrella A, Zambon CE, Ceccheti MM, Cavalcanti MG. Osteochondroma of the temporomandibular joint: a case report. Braz Dent J 2010;21:253-258. doi: 10.1590/S0103-64402010000300014.

18. Koole R, Steenks MH, Witkamp TD, Slootweg PJ, Shaefer J. Osteochondroma of the mandibular condyle. A case report. Int J Oral Maxillofac Surg 1996;25:203-205. doi: 10.1016/S0901-5027(96)80030-0.

19. Rodrigues DB, Castro V. Condylar hyperplasia of the temporomandibular joint: types, treatment, and surgical implications. Oral Maxillofac Surg Clin North Am 2015;27: 155-167. doi: 10.1016/j.coms.2014.09.011.

20. Wolford LM, Movahed R, Perez DE. A classification system for conditions causing condylar hyperplasia. J Oral Maxillofac Surg 2014;72:567-595. doi: 10.1016/j.joms. 2013.09.002.

21. Kim JS, Kim YJ, Choi EH, Kim JD. A radiographic study of the condylar hyperplasia. Korean J Oral Maxillofac Radiol 1995;25:569-575.

22. Kim SE, Kim JD. Osteochondroma and synovial chondromatosis of the temporomandibular joint. Korean J Oral Maxillofac Radiol 2002;32:41-47.

23. Seo YS, Lee GS, Kim JS, Kim JD. Synovial chondromatosis 
and osteochondroma in TMJ with CBCT images. Korean J Oral Maxillofac Radiol 2010;40:47-54.

24. Khandwala K, Waheed AA, Alvi MI, Mirza WA, Umer M, Khurshid E. Bursal synovial chondromatosis secondary to underlying osteochondroma in a child. Cureus 2017 Dec 14 [Epub]. https://doi.org/10.7759/cureus.1944.

25. Wang Y, Li L, Chen M, Yang C. Osteochondroma with secondary synovial chondromatosis in the temporomandibular joint. Br J Oral Maxillofac Surg 2016;54:454-456. doi: 10.1016/j. bjoms.2015.07.014.

26. Zha W, Zhao YF, Liu Y, Jiang L. A case of synovial chondromatosis of the temporomandibular joint secondary to preauricular trauma. Int J Oral Maxillofac Surg 2009;38: 1212-1215. doi: 10.1016/j.ijom.2009.05.005.

27. McCain JP, de la Rua H. Arthroscopic observation and treatment of synovial chondromatosis of the temporomandibular joint. Report of a case and review of the literature. Int J
Oral Maxillofac Surg 1989;18:233-236. doi: 10.1016/S09 01-5027(89)80060-8.

28. Kay PR, Freemont AJ, Davies DR. The aetiology of multiple loose bodies. Snow storm knee. J Bone Joint Surg Br 1989; 71:501-504. doi: 10.1302/0301-620X.71B3.2656722.

29. Deboise A, Roche Y. Synovial chondromatosis of the temporomandibular joint possibly secondary to trauma. A case report. Int J Oral Maxillofac Surg 1991;20:90-92. doi: 10.1016/S0901-5027(05)80714-3.

30. Helmy ES, Bays RA, Sharawy MM. Synovial chondromatosis associated with experimental osteoarthritis in adult monkeys. J Oral Maxillofac Surg 1989;47:823-827. doi: 10.1016/S0278-2391(89)80041-2.

31. Kim HS, Yun PY, Kim YK. A special case of synovial chondromatosis in the temporoman-dibular joint. Oral Biol Res 2017;41:29-33. doi: 10.21851/obr.41.01.201703.29. 